\title{
Effect of Peeling Method and Sulfitation on the Shelf Life of Frozen Green Bananas ${ }^{1}$
}

\author{
F. Sánchez-Nieva and M. Mercado ${ }^{2}$ \\ ABSTRACT
}

\begin{abstract}
The shelf life at $-10^{\circ} \mathrm{F}\left(-23.3^{\circ} \mathrm{C}\right)$ of steam-peeled, sulfited, and hot-waterpeeled unsulfited green bananas was determined. No changes in $\mathrm{pH}$ acidity and carbohydrates were observed during storage for about 290 days. During storage, irrespective of peeling treatment, a light change in Hunter $L$ and $b$ values took place indicating a slight loss in yellowness. No changes in texture were observed during storage, but tasters generally found the texture of the hot-water-peeled bananas to be softer than that of the steam-peeled fruit. Regardless of time in storage, steam-peeled sulfited samples were found inferior in appearance to hotwater-peeled samples. Browning of the inner tissue and exposed cut ends accounted for the inferior appearance of the steam-peeled sulfited samples. The flavor of the steam-peeled sulfited bananas deteriorated during storage. Hot water peeled bananas had better flavor and overall sample quality, with a shelf life of about 290 days. The changes in flavor observed in the steam-peeled sulfited samples were attributed to the action of oxidative enzymes, not to offflavors resulting from sulfitation.
\end{abstract}

\section{INTRODUCTION}

Green bananas, due to their chemical and physical characteristics, may be, for processing purposes, regarded as a starchy vegetable. Freezing and thawing cause abnormal enzyme activity in many vegetables, which results in off-flavor development (6). Therefore, for freezing vegetables, the enzyme system must be inactivated by blanching. When blanching is not possible, sulfitation has been successfully used to prevent undesirable changes in frozen products. Sánchez Nieva et al. $(9,10)$ showed that sulfited green plantains and taniers could be frozen without off-flavor development.

Sánchez-Nieva and Mercado (11) showed that, to facilitate the peeling of green bananas, the fruit may be steamed in a retort for $30 \mathrm{~s}$ at 80 $\mathrm{lb} / \mathrm{in}^{2} \mathrm{~g}\left(5.6 \mathrm{~kg} / \mathrm{cm}^{2}\right)$ or treated in hot water at $200^{\circ} \mathrm{F}$ for $30 \mathrm{~min}$. Because the steam treatment does not inactivate the enzyme system, extensive browning occurs. On the other hand, in the hot-water-peeled bananas, the enzyme system is completely inactivated. Sánchez-Nieva and Mercado (12) also showed that the enzyme-catalyzed browning reaction of the exposed tissue in green bananas could be controlled by sulfitation, but due to the very low diffusion of $\mathrm{SO}_{2}$, the polyphenol oxidase remained active in the central tissue of the fruit.

\footnotetext{
${ }^{1}$ Manuscript submitted to Editorial Board November 7, 1977.

${ }^{2}$ Chemical Engineer and Research Assistant, respectively, Food Technology Laboratory, Agricultural Experiment Station, Mayagüez Campus, University of Puerto Rico, Río Piedras, P.R. The authors wish to express their appreciation to Mrs. I. Caloni, Assistant Food Technologist, Food Technology Laboratory, for conducting the organoleptic tests.
} 
Due to the presence of active oxidative enzymes in the steam-peeled bananas, there is a strong possibility that changes in flavor and color may take place in the frozen product, with a concomitant adverse effect on quality. Consequently, a study was conducted to determine the effect of peeling method and sulfitation on the shelf life and quality of frozen green bananas.

\section{MATERLALS AND METHODS}

Green bananas of the Montecristo cultivar were used in this study. The fruit was purchased from a ripening plant, ranging in stage of development from three-quarters to full. The green fruit was stored at $45^{\circ} \mathrm{F}\left(7.26^{\circ} \mathrm{C}\right)$ until processed.

Three sets of samples were prepared for shelf-life studies. Two of the sets consisted of steam- and hot-water-peeled sliced fruit, the third of steam- and hot-water-peeled whole fruit. To reduce variations in quality and other characteristics, the bunches processed were sorted at random into two groups within each set, each of which was processed as follows:

Steam-peeled fruit: The fruit was placed in a retort and steamed for 30 $\mathrm{s}$ at $80 \mathrm{lb} / \mathrm{in}^{2} \mathrm{~g}$. After the steaming treatment, the fruit was cooled by immersion in tap water. The peel was removed by hand and the fruit trimmed to remove blemished areas and other defects. Following trimming, the fruit was cut into quarters in the two experiments in which sliced fruit was processed.

The sliced or whole fruit was sulfited by dipping for $3 \mathrm{~min}$ at $80^{\circ} \mathrm{F}$ $\left(26.7^{\circ} \mathrm{C}\right)$ in a solution of $\mathrm{K}_{2} \mathrm{~S}_{2} \mathrm{O}_{5}$ containing approximately $4,000 \mathrm{p} / \mathrm{m} \mathrm{SO}_{2}$ at $\mathrm{pH}$ 5.0. The sulfited fruit was packed in waxed cardboard containers, which were overwrapped with vapor-moisture-proof material. The fruit was frozen at $-40^{\circ} \mathrm{F}\left(-40^{\circ} \mathrm{C}\right)$ in a plate freezer and stored at $-10^{\circ} \mathrm{F}$ $\left(-23.3^{\circ} \mathrm{C}\right)$.

Hot-water peeled fruit: The fruit was immersed in water at $200^{\circ} \mathrm{F}\left(93^{\circ}\right.$ C) for $30 \mathrm{~min}$, and then cooled under tap water. The peel was removed by hand. Trimming, packaging, and freezing were done as described for steam-peeled fruit, except that the hot-water-peeled fruit was not sulfited.

Moisture, $\mathrm{pH}$, and total acidity were determined by A.O.A.C. official methods (5). Starch was determined by the method of Carter and Neubert (1), and sugars by the method of Moyer and Holgate (4).

For texture measurements, a Food Technology Corporation ${ }^{3}$ electrical recording shear press was used with a proving ring of $3,000 \mathrm{lb}$. With the instrument set to read $600 \mathrm{lb}$ at full scale, $150 \mathrm{~g}$ of fresh, thawed, or

${ }^{3}$ Trade names are used in this publication solely for the purpose of providing specific information. Mention of a trade name does not constitute a guarantee or warranty of equipment or materials by the Agricultural Experiment Station of the University of Puerto Rico or an endorsement over other equipment or materials not mentioned. 
cooked bananas were placed in the standard shear cell and measurements recorded with the plunger moving at $1.7 \mathrm{~mm} / \mathrm{s}$. Force values were determined from the recorded curves at maximum peak.

For color measurements, the frozen fruit was thawed for approximately $2 \mathrm{~h}$ at room temperature and pureed in a Waring blender. Color was measured in a Hunterlab Model D 25 color difference meter calibrated with a yellow standard ( $L=73.7, a=8.3, b=20.2$ ) with the sample placed on top of the cell of a D-25 A optical sensor.

For organoleptic tests the contents of one box (12 oz, approx. $320 \mathrm{~g}$ ) were added to 2 cups (.5 liter) of boiling water with 2 teaspoons of salt, and cooked for $10 \mathrm{~min}$ after the water started boiling again.

Two methods of organoleptic evaluation were used: Monadic rating tests for quality attributes, such as flavor, off-flavors, appearance, texture, and overall sample quality, using a 6-point hedonic scale; and ranking to compare each pair of samples in a set for flavor and appearance. When the rating method was used, single samples were presented to tasters under daylight. When the ranking method was used, the two samples in a set were compared simultaneously under red light for flavor and under daylight for color and appearance, each factor being judged independently. The results of the ranking tests were statistically analyzed by the method described by Kramer (3).

The $\mathrm{SO}_{2}$ content of the sulfiting solution was determined by the method described in the Food Chemical Cordex (2). $\mathrm{SO}_{2}$ content was measured on the thawed fruit by the method of Ross and Treadway (8). Sulfite content is indicated as $\mathrm{p} / \mathrm{m} \mathrm{SO}$.

Polyphenolase activity was determined by the method described by Ponting (7), bathing with cathecol solution a thin slice cut across the fruit.

Degree of browning in the frozen, thawed, and cooked samples was determined by visual inspection using a 5-point scale as follows: 5 , no browning; 4, light browning; 3, moderate browning; 2, moderately intense browning; 1, intense browning. Browning was observed in the exposed surface and in the interior tissue. The percentage of pieces in a box showing browning to the various intensities indicated was calculated.

\section{RESULTS AND DISCUSSION}

Table 1 includes the results of chemical analyses for the three sets of samples at different storage intervals. No differences between the steamand hot-water-peeled samples were observed during storage with regard to any of the components measured.

Hunter tristimulus values for the three sets of samples at the different storage intervals studied are given in table 2. In all samples, irrespective of peeling treatment or sulfitation, the $L$ values decreased during storage, 
TABLE 1.-Changes in chemical composition during storage

\begin{tabular}{|c|c|c|c|c|c|c|c|}
\hline \multirow[b]{3}{*}{ Storage in days } & \multicolumn{4}{|c|}{ Steam peeling } & \multicolumn{3}{|c|}{ Hot water peeling } \\
\hline & \multicolumn{7}{|c|}{ Group 1-Sliced bananas } \\
\hline & 10 & 99 & 180 & & 10 & 180 & 292 \\
\hline Total sugars- $\%$ & 0.96 & 1.02 & 0.97 & & 0.96 & 0.89 & 0.87 \\
\hline Reducing sugars- $\%$ & .21 & .21 & .20 & & .21 & .19 & .20 \\
\hline Starch-\% & 16.9 & 17.7 & 18.5 & & 19.4 & 18.7 & 19.05 \\
\hline Moisture-\% & 69.7 & 74.24 & 74.03 & & 68.5 & 73.9 & 73.37 \\
\hline Total acidity-\% & .28 & .26 & .24 & & .20 & - & - \\
\hline $\mathrm{pH}$ & 5.0 & 4.98 & 5.26 & & 5.22 & 5.12 & 5.32 \\
\hline $\begin{array}{l}\text { Ascorbic acid- } \\
\mathrm{mg} / 100 \mathrm{~g}\end{array}$ & - & - & - & & 5.41 & 9.38 & 7.45 \\
\hline \multirow[t]{2}{*}{$\mathrm{SO}_{2}-\mathrm{p} / \mathrm{m}$} & 170.0 & 133.0 & 132.0 & & - & - & - \\
\hline & \multicolumn{7}{|c|}{ Group 2-Sliced bananas } \\
\hline Storage in days & 14 & 110 & 173 & 282 & 110 & 173 & 282 \\
\hline Total sugars- $\%$ & 0.19 & 0.18 & 0.18 & 0.20 & 0.23 & 0.22 & 0.24 \\
\hline Reducing sugars- $\%$ & .10 & .09 & .11 & .10 & .16 & .14 & .16 \\
\hline Starch-\% & 18.3 & 19.5 & 17.4 & 17.0 & 18.4 & 17.3 & 19.2 \\
\hline Moisture-\% & 70.5 & - & 74.0 & 73.8 & - & 74.6 & 72.5 \\
\hline Total acidity-\% & .27 & .25 & .23 & .22 & .22 & .22 & .16 \\
\hline $\mathrm{pH}$ & 5.07 & 5.02 & 5.0 & 5.09 & 5.22 & 5.10 & 5.32 \\
\hline $\begin{array}{l}\text { Ascorbic acid- } \\
\mathrm{mg} / 100 \mathrm{~g}\end{array}$ & - & - & - & - & 5.0 & 4.7 & 5.2 \\
\hline \multirow[t]{2}{*}{$\mathrm{SO}_{2}-\mathrm{p} / \mathrm{m}$} & 215.0 & 140.0 & 145.0 & - & - & - & - \\
\hline & \multicolumn{7}{|c|}{ Group 3-Whole bananas } \\
\hline Storage in days & 18 & 102 & 182 & & 18 & 102 & 182 \\
\hline Total sugars- $\%$ & 0.22 & 0.25 & 0.25 & & 6.20 & 0.23 & 0.22 \\
\hline Reducing sugars- $\%$ & .023 & .028 & .02 & & .009 & .011 & .012 \\
\hline Starch-\% & 15.35 & 16.1 & 16.2 & & 18.05 & 17.1 & 17.5 \\
\hline Moisture-\% & 15.80 & 74.65 & 74.50 & & 73.2 & 73.7 & - \\
\hline Total acidity-\% & .21 & .20 & .19 & & .18 & .18 & .17 \\
\hline $\mathrm{pH}$ & 5.19 & 5.12 & 5.35 & & 5.38 & 5.36 & 5.50 \\
\hline $\begin{array}{c}\text { Ascorbic acid- } \\
\mathrm{mg} / 100 \mathrm{~g}\end{array}$ & - & - & - & & 6.85 & 8.05 & 7.66 \\
\hline $\mathrm{SO}_{2}-\mathrm{p} / \mathrm{m}$ & 118.0 & 167.0 & 一 & & 一 & - & - \\
\hline
\end{tabular}

the $a$ values showed only negligible variations, and the $b$ values decreasea, indicating a slight loss in yellowness.

Table 3 shows the changes in texture taking place during peeling, freezing, thawing, and cooking. The hot-water-peeled bananas had a lower shear press force value after peeling than the steam-peeled fruit in two of the three sets. However, after thawing to a temperature of $70^{\circ} \mathrm{F}$ $\left(21.1^{\circ} \mathrm{C}\right)$, the hot-water-peeled bananas had a higher shear press force value than the steam-peeled fruit in two of the three sets. When cooked, the hot-water-peeled samples had lower shear press values than the steam-peeled in two of the three sets.

When the cooked samples were rated for texture, in all three sets, 
FACTORS AFFECTING SHELF LIFE OF FROZEN GREEN BANANAS 245

tasters found the hot-water-peeled bananas to have a texture more typical of boiled green bananas than the steam-peeled. The steam-peeled were generally rated on the hard side. No significant changes in texture during storage were observed in any of the samples.

The results of ranking tests in which the steam-peeled bananas were compared with the hot-water-peeled for appearance and flavor were as follows: In all three sets of samples the steam-peeled bananas were found to be inferior in appearance, (significant at the $5 \%$ level), to the hot-

TABLE 2.-Changes in color during storage

\begin{tabular}{|c|c|c|c|c|c|c|c|c|}
\hline \multirow[b]{3}{*}{ Storage in days } & \multicolumn{4}{|c|}{ Steam } & \multicolumn{4}{|c|}{ Hot water } \\
\hline & \multicolumn{8}{|c|}{ Group 1-Sliced bananas } \\
\hline & 10 & 99 & 180 & & 10 & 99 & 180 & 292 \\
\hline Hunter L & 77.0 & 71.4 & 73.5 & & 70.0 & 64.3 & 66.5 & 64.0 \\
\hline a & .0 & -.3 & +.25 & & -1.8 & -2.1 & -1.8 & -1.7 \\
\hline b & 23.4 & 19.3 & 21.2 & & 19.6 & 16.3 & 17.05 & 15.3 \\
\hline$a / b$ & .0 & .015 & .01 & & -.09 & -.12 & -.11 & -.11 \\
\hline \multirow[t]{2}{*}{$\mathrm{E}$} & 11.13 & 8.94 & 8.11 & & 10.19 & 14.55 & 12.79 & 14.76 \\
\hline & \multicolumn{8}{|c|}{ Group 2-Sliced bananas } \\
\hline Storage in days & 14 & 110 & 173 & 282 & 10 & 110 & 173 & 282 \\
\hline Hunter L & 78.6 & 68.1 & 62.5 & 68.5 & 67.1 & 59.5 & 63.45 & 62.55 \\
\hline a & .07 & .3 & -.7 & -.1 & -2.4 & -1.4 & -1.5 & -1.2 \\
\hline $\mathrm{b}$ & 24.1 & 19.8 & 14.5 & 20.45 & 20.2 & 15.9 & 17.2 & 14.2 \\
\hline$a / b$ & .002 & .015 & -.05 & -.004 & -.12 & -.09 & -.09 & -.08 \\
\hline \multirow[t]{2}{*}{$\mathrm{E}$} & 9.0 & 9.77 & 15.45 & 9.72 & 12.57 & 17.12 & 14.5 & 15.82 \\
\hline & \multicolumn{8}{|c|}{ Group 3-Whole bananas } \\
\hline Storage in days & 18 & 104 & 182 & & 18 & 104 & 182 & \\
\hline Hunter L & 69.5 & 67.5 & 65.5 & & 66.4 & 65.9 & 64.35 & \\
\hline a & -.1 & -.7 & -.6 & & -1.7 & -2.2 & -1.5 & \\
\hline $\mathrm{b}$ & 20.9 & 18.4 & 16.4 & & 18.5 & 16.15 & 17.25 & \\
\hline$a / b$ & -.004 & -.04 & -.04 & & -.091 & -.14 & -.09 & \\
\hline $\mathrm{E}$ & 9.41 & 11.0 & 12.68 & & 12.49 & 13.69 & 11.87 & \\
\hline
\end{tabular}

TABLE 3.-Changes in texture during peeling, thawing, and cooking

\begin{tabular}{lccc}
\hline \multirow{2}{*}{ Type of product } & \multicolumn{3}{c}{ Shear press force-(lb) } \\
\cline { 2 - 4 } & Set 1 & Set 2 & Set 3 \\
\hline Hand peeled & 415.9 & 412.5 & 573.0 \\
Steam peeled & 304.5 & 270.0 & 236.0 \\
Hot-water peeled & 234.0 & 247.5 & 270.0 \\
Thawed & & & \\
$\quad$ Steam peeled & 361.5 & 396.0 & 340.5 \\
$\quad$ Hot-water peeled & 354.0 & 462.0 & 486.0 \\
Cooked & & & \\
$\quad$ Steam peeled & 114.0 & 148.5 & 117.0 \\
$\quad$ Hot-water peeled & 120.0 & 105.0 & 97.5 \\
\hline
\end{tabular}


water-peeled, irrespective of time in storage. In set 1 (sliced bananas) a significant difference in flavor was found between the steam- and hotwater-peeled samples after storage for 188 days, the hot-water-peeled sample being found to have a better flavor, significant at the $5 \%$ level. In set 2 a significant difference in flavor between the steam- and hot-waterpeeled samples appeared 289 days after storage, significant at the $5 \%$ level. In set 3 , consisting of whole bananas, a significant difference in flavor at the $1 \%$ level between the hot-water-peeled and steam-peeled samples was observed after storage for 99 days. In all three sets of samples, the hot-water-peeled bananas were found superior in flavor.

TABLE 4.-Monadic evaluation, using rating scales, of samples

\begin{tabular}{|c|c|c|c|c|c|c|c|c|}
\hline \multirow{3}{*}{$\begin{array}{l}\text { Peeling method } \\
\text { Storage in days }\end{array}$} & \multicolumn{4}{|c|}{ Stearn } & \multicolumn{4}{|c|}{ Hot water } \\
\hline & \multicolumn{8}{|c|}{ Set 1} \\
\hline & 34 & 118 & 188 & & 34 & 118 & 188 & 292 \\
\hline \multicolumn{9}{|l|}{ Ratings } \\
\hline Appearance & 1.44 & 1.38 & 1.44 & & 2.57 & 3.8 & 3.57 & 3.85 \\
\hline Flavor & 2.01 & 2.75 & 2.0 & & 3.37 & 3.0 & 3.57 & 3.75 \\
\hline Off-flavor & 4.0 & 4.9 & 3.57 & & 4.95 & 5.0 & 5.0 & 5.0 \\
\hline \multirow[t]{2}{*}{ Sample quality } & 1.92 & 2.1 & 1.85 & & 3.45 & 3.40 & 3.85 & 3.8 \\
\hline & \multicolumn{8}{|c|}{ Set 2} \\
\hline Storage in days & 14 & 119 & 191 & 289 & 14 & 119 & 191 & 289 \\
\hline \multicolumn{9}{|l|}{ Ratings } \\
\hline Appearance & 1.6 & 1.5 & 1.14 & 2.0 & 4.0 & 2.25 & 3.14 & 3.0 \\
\hline Flavor & 2.4 & 2.4 & 1.57 & 2.0 & 3.2 & 3.4 & 2.85 & 2.22 \\
\hline Off-flavor & 5.0 & 4.6 & 4.6 & 3.8 & 5.0 & 5.0 & 4.6 & 3.88 \\
\hline Sample quality & 2.4 & 1.8 & 1.3 & 1.9 & 3.8 & 3.4 & 3.0 & 2.44 \\
\hline & \multicolumn{8}{|c|}{ Set 3} \\
\hline Storage in days & 19 & 99 & 175 & & 19 & 99 & 175 & \\
\hline \multicolumn{9}{|l|}{ Ratings } \\
\hline Appearance & 1.62 & 1.50 & & & 2.75 & 3.43 & 3.33 & \\
\hline Flavor & 2.63 & 2.07 & & & 2.75 & 3.07 & 3.00 & \\
\hline Off-flavor & 4.6 & 4.28 & & & 4.65 & 4.92 & 5.0 & \\
\hline Sample quality & 1.76 & 1.92 & & & 2.4 & 3.0 & 3.1 & \\
\hline
\end{tabular}

Table 4 shows the results of the sensory tests conducted to rate the samples on a numerical scale for appearance, flavor, off-flavor intensity, and overall sample quality. Irrespective of time in storage, the steampeeled samples were given lower ratings for appearance, flavor, and sample quality than those given to the hot-water-peeled. Of the quality attributes measured, only off-flavor intensity in the steam-treated fruit showed a trend to change. In the storage interval at which a significant difference in flavor was found between the steam-peeled and hot-waterpeeled samples, the steam-peeled samples were found to have a higher intensity of off-flavor. Shelf life was shorter for the steam-peeled whole fruit than for the steam-peeled sliced bananas. 
The inferior appearance shown by the steam-peeled fruit is the result of browning. In all three sets of samples the outer surface was free of browning when frozen, thawed, or cooked. However, the inner tissue in the sliced and whole fruit suffered browning, which ranged from intense to light. Browning was observed in the frozen, thawed, and cooked stages. In the sliced fruit, browning was also observed in the exposed surface at the cut ends. A positive test for polyphenol oxidase resulted when the steam-peeled sulfited samples were treated with cathecol when fresh, and even after 300 days in storage at $-10^{\circ} \mathrm{F}\left(-23.3^{\circ} \mathrm{C}\right)$. No browning was observed in any of the hot-water-peeled samples.

The inferior flavor of the steam-peeled sulfited samples and the development of off-flavor during storage must be attributed to oxidative enzymes. When hot-water-peeled samples sulfited to levels ranging from 259 to $548 \mathrm{p} / \mathrm{m} \mathrm{SO}_{2}$ were compared for flavor with sulfited controls, no difference in flavor could be found between sulfited samples and controls when the tests were conducted after 13, 84, and 180 days in storage at $-10^{\circ} \mathrm{F}\left(-23.3^{\circ} \mathrm{C}\right)$. Therefore, flavor differences between the steampeeled sulfited bananas, in which the $\mathrm{SO}_{2}$ content was less than $200 \mathrm{p} / \mathrm{m}$, and the hot-water-peeled unsulfited fruit cannot be attributed to the effect of $\mathrm{SO}_{2}$.

The results show that frozen green bananas of good quality and shelf life can be obtained by inactivating the enzyme system before peeling. If the enzyme system is active, sulfitation does not prevent browning, nor off-flavor development during processing, freezing, and storage. Failure of $\mathrm{SO}_{2}$ to control browning and off-flavor development was shown by Sánchez-Nieva and Mercado (12) to result from the low diffusion of $\mathrm{SO}_{2}$ to the inner tissue. Since the diffusion of $\mathrm{SO}_{2}$ to the inner tissue was less in whole than in sliced fruit, a higher enzyme activity in the sulfited steam-peeled whole fruit may account for the lower shelf life observed in this set of samples.

\section{RESUMEN}

Lotes de guineos ${ }^{4}$ verdes se congelaron siguiendo dos procedimientos distintos: 1) tratados en un autoclave por 30 segundos a una presión de vapor de $60 \mathrm{lbs} /$ pulgada cuadrada (5.6 $\mathrm{kg} / \mathrm{cm}^{2}$ ), y luego enfriados en agua, pelados a mano y sulfitados sumergiéndolos por 3 minutos en una solución de $\mathrm{K}_{2} \mathrm{~S}_{2} \mathrm{O}_{5}$ que contenía alrededor de 4000 ppm de $\mathrm{SO}_{2}$ a pH 5.0. La fruta sulfitada se envasó en recipientes de cartón encerado, los que luego se envolvieron con papel impermeable a la humedad y otros vapores; y 2) la fruta sumergida por 30 minutos en agua a $200^{\circ} \mathrm{F}$. ( $3^{\circ}$ C.) y enfriadas luego. Una vez pelada se envasó como se describió anteriormente, y después de congelada a $-40^{\circ} \mathrm{F}$. $\left(-40^{\circ} \mathrm{C}\right.$.) se almacenó a $-10^{\circ} \mathrm{F}$. $\left(-23.3^{\circ}\right.$ C.). A intervalos regulares durante el almacenamiento, las muestras se analizaron para contenido en humedad, azúcares totales y reductores, acidez, pH, ácido ascórbico (en las no sulfitadas), textura y color. A los mismos intervalos de tiempo se llevaron a cabo evaluaciones sensoriales para determinar los cambios en sabor, apariencia, textura, niveles de sabores extraños y calidad de las muestras.

Los resultados de estos estudios demostraron que, durante un almacenamiento que duró 292 días, no se observaron cambios en los componentes químicos antes indicados ni en

\footnotetext{
${ }^{4}$ Bananos.
} 
la textura. En cambio, se observó un ligero cambio en el color, disminuyendo los valores para los atributos de color $L$ y $b$ medidos en un metro Hunterlab Modelo 25.

Las pruebas sensoriales demostraron que las muestras tratadas a vapor y sulfitadas eran inferiores en apariencia y calidad general a las tratadas en agua caliente y que no se sulfitaron. Las muestras tratadas a vapor y sulfitadas desarrollaron sabores extraños durante el almacenamiento, por lo cual la duración en almacén a $-10^{\circ} \mathrm{F}$. $\left(-23.3^{\circ} \mathrm{C}\right)$ fue más corta que las de las muestras tratadas con agua caliente, las cuales no cambiaron en sabor y calidad. Los cambios adversos que sufrieron las muestras tratadas a vapor y sulfitadas se atribuyen a la acción de las enzimas oxidantes, ya que se comprobó que muestras tratadas con agua caliente y sulfitadas a niveles superiores a los usados para sulfitar las muestras tratadas a vapor no tenían sabores extraños detectables.

\section{LITERATURE CITED}

1. Carter, J. H., and Neubert, A. M., 1959. A rapid determination of starch in apples, J. Agric. Food Chem. 2(2): 70-2.

2. Food Chemical Codex, 1963. Publ. 1143, Nat. Acad. Sci., Nat. Res. Counc., p. 184, Washington, D.C.

3. Kramer, A., 1960. A rapid method for determining significance of differences from rank sums, Food Technol. 14(11): 576-81.

4. Moyer, C., and Holgate, K. C., 1948. Determination of alcohol insoluble solids and sugar content of vegetables, Anal. Chem. 20(5): 472-4.

5. Official Methods of Analyses of the Association of Official Agricultural Chemists, $12 \mathrm{ed}$, Washington, D.C., 1975.

6. Olson, R. L., and Dietrich, W. C., 1968. Vegetables: Characteristics and the stability of the frozen product: in The Freezing Preservation of Foods, 4th ed, D. K. Tressler, W. B. Van Arsdel, and M. J. Copley, Ed, vol. 2, 83-106. Avi Publishing Co., Westport, Conn.

7. Ponting, J. D., 1944. Cathecol test for frozen fruit, Quick Frozen Foods 7(5): 31.

8. Ross, L. R., and Treadway, R. H., 1960. A rapid method for the determination of sulfur dioxide in sulfited pre-peeled potatoes, Am. Potato J. 37: 102-7.

9. Sánchez-Nieva, F., Hernández, I., and Bueso, C., 1975. Studies on the freezing of green plantains, II., Sulfitation to control browning, J. Agric. Univ. P.R. 59(2): 92-106.

10.,,---1977 . Control of browning in lye-peeled taniers, J. Agric. Univ. P.R. 61(4): $489-500$.

11. - - - 1978. Effect of peeling method on the absorption of aqueous bisulfite by green bananas, J. Agric. Univ. P.R. 62(2): 191-8.

12. - Mercado, M., 1978. Control of enzymamatic browning in green bananas for freezing, J. Agric. Univ. P.R. 62(3): 232-40. 